Dragana Kovačić

Narodni muzej Beograd

https://doi.org/10.18485/bgd_nlistiek_30.2018.ch11

\title{
OD STEDELEJKA DO HEMENTEMUSEUMA: O DVE IZLOŽBE JUGOSLOVENSKE I SRPSKE UMETNOSTI
}

\section{Abstract}

In September of 1932, an exhibition of Yugoslav art opened at the Stedelijk Museum in Amsterdam. One year earlier, in October 1931, the Committee for the Promotion of Dutch Art in Yugoslavia, headed by C. D. Merens, the honorary Consul General of the Kingdom of Yugoslavia in Amsterdam, had donated forty-two works by contemporary Dutch artists to what was at the time the Museum of Contemporary Art in Belgrade. The goal of the exhibition at the Stedelijk Museum was to use visual art in order to present the Yugoslav cultural space to the Dutch public and likewise improve the reputation of the Kingdom of Yugoslavia abroad. The exihibition was then transferred to the Brussels Fine Arts Palace. The exhibition's honorary sponsor was Prince Pavle Karađorđević, while Milan Kašanin, then-director of the Museum of Contemporary Art, had a key role in professional communication with Merens and the Stedelijk Museum's director, Cornelis Baard. Collection and professional preparation was carried out by the painting section of the Cvijeta Zuzoric Association of Friends of Art. The response from the Dutch and Belgian public in 1932 was impressive: the exhibition was featured in dozens of critical and reference works.

In 2004 the Gemeentemuseum in The Hague showed 188 works of Serbian, Yugoslav and European modernists from the National Museum in Belgrade. The main curator of the exhibition was Dr. John Sillevis, while curators from the National Museum were in charge of its realization. In showing Yugoslav and international works side by side, Dr. Sillevis was not concerned with the question of "influence" that occupied critics of the last century; instead, through a comparison of currents of world Modernism, he showed the originality and uniqueness of Serbian and Yugoslav art. The Dutch media's response was incomparably weaker than that of 1932 . The reason for that most likely lies in the fact that the 2004 exhibition took place in the shadow of the civil war of the 1990s, and at a time when Serbia's international reputation was destroyed.

Keywords: modern art, Yugoslav contemporary art, international cultural politics, cultural influence, art criticism. 


\section{Amsterdam - Brisel 1932.}

U septembru 1932. godine u Stedelejk muzeju u Amsterdamu otvorena je izložba jugoslovenske savremene umetnosti. Godinu dana ranije, u oktobru 1931, Odbor za širenje holandske umetnosti u Jugoslaviji poklonio je tadašnjem Muzeju savremene umetnosti u Beogradu ${ }^{1}$ četrdeset i dva dela savremenih holandskih umetnika. ${ }^{2}$ Zbirka koja je u muzejskoj svakodnevici dobila naziv Poklon grada Amsterdama, na dobar način predstavlja umetničku produkciju u Holandiji sa kraja devetnaestog i iz prvih decenija dvadesetog veka. ${ }^{3}$ Ona i do danas čini jednu od najvrednijih celina u okviru Zbirke strane umetnosti Narodnog muzeja u Beogradu.

Dela koja su za beogradski muzej prikupljena od holandskih umetnika i kolekcionara na dobrovoljnoj bazi, ili su bila otkupljena, osnažila su koncepciju ove, $\mathrm{u}$ to vreme, mlade institucije. Pored nabavke dela srpskih i jugoslovenskih umetnika, Muzej savremene umetnosti je bio aktivan i u sakupljanju radova stranih autora koji su bili grupisani prema nacionalnim školama. Bilo da je reč o delima domaćih ili stranih umetnika, kolekcionarska politika Muzeja je bila usmerena prema onim ostvarenjima čija je vrednost bila potvrđena u krtitičkoj javnosti vremena, dakle prema radovima koji su pripadali središnjim tokovima umetničke produkcije. Iz ovakve koncepcije bila su isključena dela avangardnih umetnika.

Izvesno je da je holandska donacija, pored velike umetničke vrednosti i obogaćenja kolekcije našeg Muzeja, ujedno i otvaranja galerije holandske umetnosti na stalnoj postavci, predstavljala podsticaj za proširenje saradnje dve države. Izložba Jugoslovenske savremene umetnosti u Stedelejku, koja je inicirana ovim poklonom, imala je za cilj da, posredstvom vizuelnih umetnosti, predstavi naš kulturni prostor holandskoj javnosti, ali takođe i da poboljša ugled Kraljevine Jugoslavije u inostranstvu. ${ }^{4}$ $\mathrm{Na}$ taj način, značaj umetničkih izložbi, izlazi izvan okvira kulture i preusmerava se prema političkim i diplomatskim aktivnostima, a sam kulturni sadržaj postaje jedno od sredstava zvanične državne međunarodne komunikacije.

Ovaj, najčešće revijalan način predstavljanja kulturnog sadržaja, može se

1 Muzej savremene umetnosti je spojen sa Narodnim muzejom (tada Historijsko-umetničkim muzejom) 1935. godine. Do 1944. ovaj muzej je nosio naziv Muzej kneza Pavla.

2 Odbor za širenje holandske umetnosti u Jugoslaviji osnovan je u okviru Društva ljubitelja Jugoslavije. Osnivač ovoga društva bio je počasni generalni konzul Kraljevine Jugoslavije u Amsterdamu, gospodin Kornelis Dirk Merens. Дергенц 2014: 15-27.

3 Reč je o delima umetnika koji su bili uključeni u postimpresionističke tokove, u kojima posebno mesto pripada Haškoj školi. Pored Van Goga (Van Gogh), Brajtnera (Breitner), Izraelsa (Israëls), Cvarta (Zwart), itd, u okviru Poklona grada Amsterdama nalaze se slike Jana Toropa (Jan Toroop), kao i umetnica Lizi Ansing (Lizzy Ansingh) i Suze Bishop-Robertson (Suze Bisschop-Robertson) koje su krajem devetnaestog i početkom dvadesetog veka delovale u okviru grupe Amsterdamske gospođice (Amsterdamse Joffers). Iz ove, stilski ujednačene poklon-zbirke, izdvaja se avagnardno ostvarenje Pita Mondrijana (Piet Mondriaan), „Kompozicija II“ iz 1929. Дергенц 2014: 18.

4 O vrednosti i značaju poklona govori i pismo zahvalnosti g-dinu Merensu koje Milan Kašanin upućuje preko Ministarstva prosvete, br 305 od 26. okotbra 1931. AJ F66, 321-540. 
posmatrati kao nastavak učešća na svetskim izložbama na kojima je Srbija bila prisutna od kraja devetnaestog veka. Treba pomenuti uspeh naše umetnosti na Svetskoj izložbi u Rimu (1911) i Londonu (1915). Za vreme Kraljevine Jugoslavije, gostovanja naših umetnika se nastavljaju izložbama u Parizu (1931, 1937), Barseloni, Filadelfiji, itd, te konačno izložbom skulptora Tome Rosandića u Roterdamu koja je održana par godina pre izložbe u Amsterdamu.

Komunikacija putem kulture koja je u službi spoljne politike, bila je započeta diplomatskim aktivnostima Kraljevine SHS i zapravo je predstavljala strateško mesto koje je utvrđeno neposredno posle stvaranja države 1.12.1918. godine. Početkom 1919. ministar spoljnih poslova Kraljevine SHS, dr Ante Trumbić, uputio je pismo zvaničnicima niza zemalja sa inicijativom za uspostavljanje službenih odnosa. Između ostalih, ovo pismo bilo je upućeno i ministru spoljnih poslova Kraljevine Holandije, g-dinu Van Karnebeku (Herman Adriaan van Karnebeek). Uspostavljanje diplomatskih odnosa dve zemlje nije teklo lako niti jednostavno. Posle prekida tokom 1920. i 1921, odnosi su normalizovani 1922. godine, i to obostranom željom za intenziviranjem pre svega privrednih, konkretno trgovinskih odnosa (Милошевић 2006: 128,129).

Delatnost gospodina K. D. Merensa kao i Društva ljubitelja Jugoslavije imala je takođe privredne i trgovinske ciljeve (Огњановић 2014: 40, 41). Imajući to u vidu, kao i prethodne diplomatske probleme, možemo utvrditi kako su izložba iz 1932, kao i prethodni poklon, zapravo izlazili iz kulturnog i umetničkog domena.

Pored proširenja odnosa na izvan umetničkim planovima, gostujuće izložbe imaju mogućnost da doprinesu promovisanju kulturnog identiteta jedne sredine u drugoj. Predstavljanjem Jugoslovenske savremene umetnosti u Amsterdamu, a zatim i Briselu, jednako kao i izložbama koje su tokom treće decenije dvadesetog veka bile prikazivane u Evropi i Americi, želelo se pokazati na koji način je Jugoslavija, uz sve osobenosti istorijskog nasleđa, bila povezana sa zapadnim kulturnim prostorom. Izlazak iz zemlje i kontakt sa stranom javnošću i njenom kritikom, kao i stručnom i laičkom publikom, bilo je značajno za sagledavanje naše umetničke produkcije iprema aktuelnim tokovima. Isto tako, za same autore je ovakvo iskustvo moglo da bude korisno i opravdano, jer su gostujuće izložbe obično bile i prodajne.

Izložba u Amsterdamu organizovana je pod počasnim pokroviteljstvom kneza Pavla Karađorđevića, a ključna ličnost u stručnoj komunikaciji sa direktorom Stedelejka, Kornelisom Bardom, i K. D. Merensom bio je Milan Kašanin, tadašnji direktor Muzeja savremene umetnosti. Sakupljanje i stručnu obradu radova realizovala je Likovna sekcija Udruženja prijatelja umetnosti „Cvijeta Zuzorić“. ${ }^{5}$ Udruženje je bilo mesto na kome su promovisani likovni događaji. Svake godine Udruđenje je organizovalo dve velike kolektivne izložbe, prolećnu, koja je predstavljala jugoslovenske umetnike i jesenju, koja je prikazivala aktuelna ostvarenja beogradskih umetnika. Isto tako, ovo

5 Ovo Udruženje je osnovano 1922. godine i to delatnošću Branislava Nušića, tadašnjeg načelnika Umetničkog odeljenja Ministarstva prosvete, koji je pozvao beogradsku gospodu, književnike i umetnike na sastanak u Ministarstvo i podsetio ih je da se naš svet slabo interesuje za umetnost i književnost, zbog čega umetnici žive i rade u veoma lošim uslovima i zbog čega bi trebalo osnovati udruženje koje bi propagiralo umetnost, priređivalo izložbe, koncerte i izdavalo knjige. Cerović 2011. 
Udruženje je posredovalo i organizovalo gostovanja naših umetnika u inostranstvu kao i stranih izložbi u Beogradu. Ova dva polja delovanja nisu bila uzročno povezana, te tako izložbe nisu rađene po principu uzajamnosti, nego na osnovu izvodljivosti i realnih okolnosti. U Beogradu su tokom treće i četvrte decenije bili prikazani radovi nemačkih, francuskih, čeških, mađarskih, britanskih savremenih umetnika, ruskih emigranata, stare poljske i francuske grafike, itd. (Cerović, Nav. delo).

Kao mesto koje je okupljalo jugoslovensku likovnu scenu, Udruženje „Cvijeta Zuzorić" je imalo mogućnost da svoje aktivnosti proširi i prema prezentaciji naših umetnika u inostranstvu. Rezultat ove vrste delatnosti bile su i velike jugoslovenske izložbe u Amsterdamu, Briselu, Košicama i Brnu.

Pored princa Pavla, u pokroviteljstvo izložbe u Amsterdamu su se uključili zvaničnici iz redova diplomatije, ministri vlade Kraljevina Holandije i Jugoslavije, umetnici i javne ličnosti. Brojni uglednici, njih više od četrdeset, bili su grupisani u tri tela, iz obe zemlje, i to kao počasna predsedništva i počasni komiteti. ${ }^{6}$ Ovako visoki državni i institucionalni karakter i značaj koji je sa te strane dat našoj izložbi treba sagledavati, dakako, u svetlu značaja prethodnog poklona. U realizaciji izložbe u Amsredamu 1932, kao i prethodne godine, ključna je bila aktivnost konzula gospodina Merensa. Verovatno je upravo on posredovao kod direktora Stedelejka, Kornelisa Barda, koji je prisustvovao otvaranju sala holandske umetnosti u Beogradu. O inicijativi Barda za izložbu u Amsterdamu svedoči i pismo koje je Kašanin uputio Ministarstvu prosvete Kraljevine Jugoslavije, tražeći ujedno i finansijsku pomoć od 100.000 dinara. $^{7}$ Sa druge strane, jugoslovenska izložba se uklapala u aktuelnu politiku Stedelejka. Naime, Kornelis Bard, koji je profesionalnu karijeru započeo kao kustos u Stedelejku, od 1920. do 1936. je bio direktor ovoga muzeja. Početkom 1932. on je, zajedno sa upravom, redefinisao ciljeve i koncepciju delovanja, što je podrazumevalo dinamičniju nabavku umetničkih dela. Pored holandskih modernista, Haške škole i postimpresionista, politika nabavke je bila proširena i usmerena prema svetskoj savremenoj sceni.Takođe, u ovom periodu u Stedelejku su osnovana odeljenja za primenjenu umetnost, dizajn i plakat.

Činjenica da je jugoslovenska umetnost prikazana u ovako ugledom muzeju, pokazuje da joj je u holandskoj javnosti bio dat veliki značaj. Bila je prikazana u pet reprezentativnih sala koje su svečano otvorene 24. septembra. Tokom narednog meseca, do 23. oktobra, holandska publika je videla radove naših umetnika koji su delovali u prve tri decenije dvadesetog veka.

Jugoslovenska izložba u Amsterdamu bila je organizovana po pozivu na koji se odazvalo trideset i osam umetnika sa sto sedamdeset i šest radova: slika, skulptura, grafika, akvarela, pastela, gvaševa i crteža. Milan Kašanin, koji je bio član

6 U jugoslovenskom predsedništvu su bili Boško Jevtić, ministar spoljnih poslova, D. Kojić, ministar obrazovanja, kulture i sporta, itd,kao i ministar obrazovanja iz Haga, te opunomoćeni izaslanik ambasadora Holandije iz Atine. Jugoslovenski komitet je brojao osam uglednih ličnosti iz Beograda, Zagreba i Ljubljane, a holandski dvadest i dva člana, među kojima su bili i gradonačelnik Amsterdama, umetnici i predsednici umetničkih udruženja.

7 AJ F 66, 381-618. Dopis br. 136 od 12. maja 1932. 
radnog komiteta izložbe i koji je pisao uvodni tekst kataloga, imao je primedbe u vezi sa obimom izložbe i njenom koncepcijom. On je zapazio da ima „malo previše umetnika“, kao i da izložbi nedostje strožija selekcija radova, koja bi doprinela kvalitetnijem predstavljanju naše umetničke produkcije (Кашанин1932: 311-312). Ipak, zahvaljujući uglednim imenima jugoslovenske likovne scene, Ivanu Meštroviću, Tomi Rosandiću, Sretenu Sretenoviću, Milanu Konjoviću, Savi Šumanoviću, Milivoju Uzelcu, Zori Petrović i Milanu Milovanoviću, Kašanin ocenjuje kako je ova „izložba važna - kako po mestu i prostorijama u kojima je otvorena, tako i po raznovrsnosti i količini poslanih radova." (Кашанин, Нав. дело)

Kao direktor Muzeja savremene umetnosti u Beogradu koji je sakupljao i otkupljivao dela savremene jugoslovenske umetnosti, među kojima su umetnici koji su izlagali u Amsterdamu, Kašanin je bio veliki autoritet, pouzdani saradnik Princa Pavla, generalnog pokrovitelja ove izložbe, kao i uvaženi znalac sa opštim i temeljnim pogledom i shvatanjem istorije umetnosti na našim prostorima. Budući da nije mogao da utiče na izbor umetnika i radova, jer je u pitanju bila revijalna izložba koju je organizovalo Odeljanje za umetnost Udruženja „Cvijeta Zuzorić“ sa umetnicom Olgom Stanojević koja je bila sekretar Odeljenja, Kašaninova uloga bila je da u uvodnom tekstu objedini različite umetničke poetike i da ih predstavi u kontekstu jugoslovenskog kultrunog nasleđa.

U uvodnom tekstu kataloga izložbe 1932 u Amsterdamu, Kašanin podseća da je ključni razlog za ovu izložbu bio poklon koji je Muzej savremene umetnosti primio iz Amsterdama, čime je započela muzeološka obrada i istorizacija moderne holandske umetnosti kod nas, na čemu posebnu zahvalnost ukazuje K. D. Merensu (Kašanin 1932a). Kako bi što bolje objasnio posebnost jugoslovenske likovne scene, Kašanin $\mathrm{u}$ jednom sažetom vidu, odslikava široki istorijski raspon jugoslovenske kulturne teritorije, od bogate tradicije srednjeg veka između Dalmacije i Srbije, do petnaestog veka, kada nastupa stagnacija u odnosu na Evropu u kojoj cveta renesansa i barok, a zatim ukazuje na osobenu poziciji naših zemalja u odnosu na dominantne Austriju i Austrougarsku sa jedne, i Veneciju sa druge strane. Ovim pregledom je zapravo ukazano na okolnosti koje su uticale na stvaranje i profilaciju moderne umetnosti u Jugoslaviji. Pri tome je Prvi svetski rat veoma mnogo odredio sudbinu Moderne, naročito u Srbiji. Upoznajući holandskog čitaoca sa istorijskim kontekstom, uslovima u kojima nastaje savremena umetnost kod nas, i oslanjajući se pri tome na narativ o našoj baštini i njenoj svojstvenosti, Kašanin posredno upućuje na način na koji treba da se posmatra i razume jugoslovenska umetnost. U predstavljanju samih umetnika, on referira na Minhensku akademiju i Pariz, dve velike škole u kojima su se formirali impresionisti iz prve decenije dvadesetog veka. Nezaobilazna su u njegovom pregledu, kojim nastoji da što bolje obrazloži nastanak jugoslovenske Moderne, dva imena, Nadežda Petrović i Miroslav Kraljević, kod kojih naglašava uticaje Sezana i fovista. U drugu grupu Kašanin svrstava mlađu generaciju, Mila Milunovića, Marka Čelebonovića, Jurja Plančića, Savu Šumanovića i Marina Tartalju, koji svoju kolorističku koncepciju ispituju u pejzažima, mrtvim prirodama i enterijerima. Navodeći dalje imena učesnika na izložbi, kao i one autore koji nisu prisutni, ali koji daju okvir celoj produkciji, kao što su Jovan Bijelić i Ignjat Job, Kašanin posebno izvdaja svaku individualnu osobenost 
i posebno naglašava suživot različitih ideja koje opstaju zajedno. Ipak, posebno mesto je dato Ivanu Meštroviću i Tomi Rosandiću. Na kraju uvodnog teksta on zaključuje da se, i pored velike raznovrsnosti i bogatstva produkcije, ne može govoriti i jednoj „jugoslovenskoj školi“, bar ne u onom smislu kakve su holandska ili francuska. Kašanin smatra da jugoslovenski umetnici još uvek imaju veoma različite stavove u pogledu stila, jer je teška prošlost još uvek prisutna, ali da se može verovati u budućnost ovih umetnika (Kašanin, Nav. delo: 11,12). Na ovaj način je Milan Kašanin predstavio i za ovu priliku protumačio jugoslovensku likovnu umetnost. Sa druge strane, uvek je zanimljivo pitanje kako nas drugi vide i razumeju, pogotovo kada je reč o manjim ili manje uticajnim kulturnim sredinama, koje se nalaze izvan glavnih tokova koji određuju kulturu jednog doba. Drugim rečima, pitanje je na koji način centar prepoznaje i vrednuje periferiju. Prema holandskoj (kasnije i belgijskoj) štampi koju nam prenosi Kašanin u Српском къижевном гласнику 1932. ${ }^{8}$ očita je podudarnost mišljenja holandskih kritičara sa stanovištem Kašanina, naročito onim koji se odnosi na nepostojanje ,jugoslovenske škole“. Može se postaviti pitanje da li je njegov uvodni tekst u katalogu izložbe uticao na ocene i mišljenja koja su potom izneli holandski časopisi.

U opštem pregledu ovih tekstova, uočava se jedna konstanta, da je ,jugoslovenska savremena skulptura odlična, slikarstvo osrednje, a umetnički život bujan“. Prema oceni Kašanina, najrelevantnija je kritika koja je izašla u listu socijalista Het Volk, a čiji autor P. F. Sanders (P. F. Sanders) kaže: „Ova izložba je na prvom mestu značajna po onome što je donela iz oblasti skulpture ... Tu nas prvo zadobivaju Meštrović i Rosandić. Obojica se izražavaju kako u velikim i monumentalnim oblicima tako u intimnoj i maloj plastici. Obojica su majstori prvog reda. Osobine su im, međutim, veoma različite. Rosandićevo delo je oporo i strasno, vrlo sensualno, puno čovečnosti, toplo i iskreno. Veličanstvene i snažne u pokretu su njegove skulpture, moćne, a ipak gipke, nežne i osećajne u strukturi, bez preterane mekoće ili rafinmana. Meštrovićevo delo je monumentalnije ali u isto vreme intelektualnije, više epsko ali i više literarno. Kad Meštrović vaja „Majku sa detetom“, njegova skulptura postaje simvol materinstva ..." (Cit. prema: Кашанин 1932)

Što se tiče slikarstva, holandska štampa takođe je jedinstvena. Sanders ocenjuje da su, u poređenju sa holandskim, a naročito francuskim slikarstvom, jugoslovenski slikari od male internacionalne važnosti: „Talenata ima dosta, ali nedostaje originalnosti.“ Vidljiv je uticaj francuskih „ekstremista“ (fovista, op. a) kod mlađih, a Minhenske škole kod starijih." Uticaji sprečavaju „razvitak ličnog izraza“, zaključuje Sanders, kao i drugi kritičari. Sanders, pak, ističe Konjovića kao „umetnika sa dosta turobnom paletom", Tone Kralja i njegove ženske portrete, France Kralja kao „mističara zlatne snage“, Mila Milunovića i Jure Plančića kao „dobre koloriste“, Ivana Radovića i njegov „poetizam i narodnu umetnost“, kao i „dekorativnu snagu“ Save Šumanovića, Milivoja Uzelca i njegovu „optimističku snagu koja otkriva dobrog

8 M. Kašanin u ovom kao sledećim tekstovima predstavlja i komentariše natpise u holandskoj i belgijskoj štampi. Ovde prenosimo njegovo tumačenje i izbor, budući da nismo za ovu priliku imali uvid u originalne natpise. Videti: Кашанин 1932. 
ilustratora“, te Riharda Jakopiča kao „osećajnog impresionistu“. Drugi kritičari uočili su Zoru Petrović, Nanda Vidmara, Ferda Vesela, Živorada Nastasijevića. Holandski kritičari izdvojili su Tone Kralja, kod koga su uočili najviše originalnosti i najmanje stranih uticaja.

Izvesno je da ovi tekstovi nisu bili samo informativni, te da je jugoslovenska izložba pobudila veliku pažnju i ozbiljne analize, kritike i prikaze. Holandski kritičari su detaljno proučili i ocenili radove naših umetnika. Pitanje je da li su oni na pravi način razumeli značaj postojanja više tendencija, i da li, po njihovom mišljenu, nepostojanje jedinstvene škole može da se kvalifikuje kao nedostatak. Ili činjenica da je likovno stvaralaštvo bogato i raznovrsno znači prednost i kvalitet po sebi. Posebno je kompleksno pitanje odnosa prema francuskoj modernoj umetnosti, pri čemu se našem slikarstvu zamera da previše prati zbivanja u Parizu. Od polovine devetnaestog veka iz Pariza, koji je bio metropola Moderne, širile su se nove ideje i likovni postupci koji su izmenili likovnu umetnost u čitavoj Evropi, Severnoj Americi, dopirući i do Dalekog Istoka. Drugim rečima, svetska moderna umetnost je iznikla na pariskoj, odnosno francuskoj umetnosti Jugoslovenski slikari su se sreli sa izvornim francuskim impresionizmom relativno kasno, tri ili četiri decenije posle njegovog nastanka, ali su za vreme svojih boravaka u Parizu bili svesni te činjenice i sa potpunim razumevanjem su pristupili tada aktuelim pravcima kao što su fovizam, intimizam ili postkubizam. Jugoslovensko slikarstvo, od Nadežde Petrović do Marka Čelebovnovića, ne pokazuje da su ideje preuzete, niti da se radi o pukom ugledanju, već je reč o sopstvenom izrazu u korišćenju jezika pojedinih pravaca ili modernog slikarstva uopšte.

Odmah posle zatvaranja u Amsterdamu, izložba je, po želji i o trošku belgijske vlade, preneta u Brisel gde je priređena u sedam sala Palate umetnosti. Činovnik u Poslanstvu Kraljevine Jugoslavije piše: „, [...] u Briselu u vremenu od 10. do 28. decembra će se održati velika izložba jugoslovenske umetnosti - slikarstva i vajarstva pod visokim pokroviteljstvom Nj.V. Princa Pavla, naše i belgijske vlade. Tom prilikom Belgijsko-Jugoslovenska trgovačka komora [...] priređuje veliki banket. ${ }^{\text {" }} \mathrm{U}$ Briselu je izložba takođe pobudila živ interes u javnosti i kritici. Kašanin beleži: „Pri ruci nam je oko šestdeset kritika i beležeka koje su doneli belgijski listovi u Briselu, Anversu, Ganu i Liježu. [...] Mislimo da je opravdano uverenje da su inostrana mišljenja o našoj umetnosti interesantna čak i onda kada se sa njima ne slažemo, jer mogu biti povod za razmišljanja i diskusiju." (Кашанин 1933: 63-66)

Kašanin izdvaja Šarla Bernara (Charles Bernard), kritičara dnevnog lista La Nasion Belž (La Nation Belge): „Treba da se vratimo još jedanput na modernu jugoslovensku umetničku izložbu koja je otvorena u Palati umetnosti. Na njoj se čovek susreće sa vatrenim, patetičnim izrazom jedne nacionalne duše koja je puna najdivnijih tradicija $[. .$.$] na njoj se zameću najveličanstvenije nade. To je umetnost koju bismo$ najradije nazvali epskom i u kojoj je sve u znaku gordosti i snage. Prometejska umetnost." Ovaj kritičar ističe Meštrovića, Rosandića kao i čitavu selekciju skulpture, France Kralja i Lojze Dolinara, zaključujući da po dometima u ovoj umetnosti, Jugoslavija prednjači

9 U potpisu Poslanik ,.....“ (potpis nečitak), iz pisma Poslanstva Kr. Jugoslavije u Belgiji (pov. № 812/a) poslatog Ministarstvu prosvete 13.11.1932. AJ Fond 66, fascikla 381-618. 


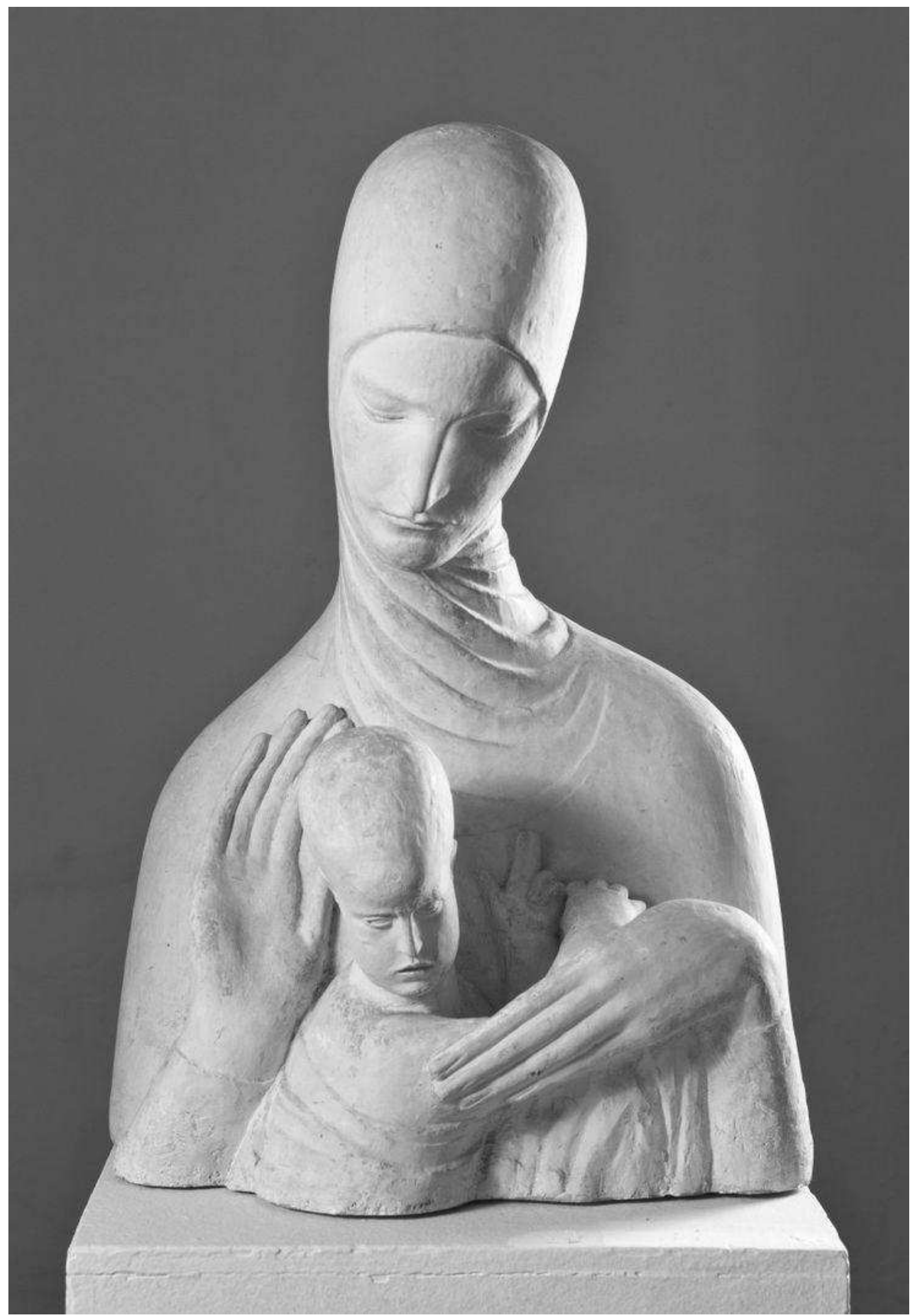

[Slika 1: Ivan Meštrović, „Majka i djete“ / „Bogorodica sa djetetom“] 




[Slika 2: Toma Rosandić, „Ecce Homo“] u odnosu na druge zemlje (Cit. prema: Кашанин, Нав. дело, 63). Što se tiče slikarstva, Bernar primećuje kako su ovim širokim izborom prikazani svi pravci koji su se pojavili u poslednjih nekoliko decenija (od početka veka), dok centralno mesto celokupne produkcije pripada impresionizmu koji je pomešan sa ekspresionizmom. Prema njegovom mišljenju, ističu se radovi Čelebonovića, Globočnika, Jakopiča, Josića, Konjovića, Kralja, Milunovića, Nastasijevića, Pomorišca, Radovića, Šumanovića i Uzelaca.

List Le Métropole objavio je: „Izložba [...] otkriva jednu novu školu, punu divnih ostvarenja." Kritičar ovog lista takođe ističe kolorističke vrednosti slika, bogatu paletu, oštru u kontrastima, ali isto tako smatra da se „svi drže neke strane škole“, i to Renoara (Renoir), Sezana (Cézanne), Matisa (Matisse) i fovista. U tim poređenjima on izdvaja Šumanovićev „Akt“ i „Doručak na travi“, Radovićevu „Kompoziciju“, Josićev „Akt“, Uzelčevu „Odalisku“, dok za Nastasijevićeve stare ulice Beograda nalazi pandan u Utrilu. „Jugoslavija je očigledno privilegisana zemlja skulpture. Meštrović i Rosandić su „svetske veličine“. Oni vide na veliko, tačno i snažno“, zaključuje ovaj autor (Исто).

U časopisu Le XXe siècle kritičar Marsel Šmiz (Marcele Schmitz) kaže:

Plemenitost i veličinu [...] treba da tražimo na drugom mestu, kod drugih naroda. U Jugoslaviji, zemlji pastira i ratnika, zemlji divljih snaga, našla su se dva velika skulptora, dva epska čoveka koja su sposobna da izvedu dela najširih srazmera, Rosandić i Meštrović, jedan možda čovečniji, drugi više titanski, ali obojica herojski u ovom našem izopačenom svetu, oni se javljaju kao autentični naslednici renesansnih vladara." (Исто, 65)

Ima u mišljenju Marsela Šmiza klišeizirane predstave o sredini o kojoj se nije dovoljno znalo, a koja je slovila za zemlju junaka i iskonske borbenosti. Ona se sada, sasvim primereno, upravo kroz sklupturu otkriva kao nov i svež potencijal koji predstavlja alternativu ,izopačenom svetu“. U ovakvom stavu se prepoznaje recidiv romantičarskog pristupa nepoznatim terenima i teritorijama, a koji se zapravo formira na pozicijama evrocentrizma. To je ono pridodavanje značenja određenim entiteima koji se tretiraju kao objekti koje, na osnovu svoga modela/lika, shvataju, definišu i simuliraju drugi. ${ }^{10}$

Odziv holandske i belgijske javnosti 1932. godine je bio impresivan. Kako nas informiše Milan Kašanin, bilo je objavljeno

10 Edvard Said (Edward Saïd) ovaj tumači kako je „[...] bezlično zapadnjačko uverenje da je moguć opis opštih, kolektivnih fenomena i u njihovoj tendenciji da se realnosti manje stvaraju na osnovu Orijenta, a više na osnovu vlastitih opažanja." Said 2008:238. 
preko dvadeset, „kritika i referata o našoj izložbi, i one izlaze još neprestano“. Ovakva reakcija se neće ponoviti šezdeset i dve godine kasnije, kada u Hagu bude prikazana izložba „Beograd - Pariz. Remek dela Narodnog muzeja u Beogradu“ (Belgrado Parijs. Meesterwerken uit het Natonale Museum van Belgrado).

\section{Hag 2004.}

Podsterk za organizovanje ove izložbe došao je iz Holandije. Godine 2003. Narodni muzej u Beogradu su posetili profesor Henk van Os (Henk van Os), nekadašnji direktor Rejksmuseuma (Rijksmuseum), Vim van Krimpen (Wim van Krimpen), direktor haškog Hementemuseuma i dr Džon Silevis (John Sillevis), glavni kustos ovog muzeja. Oni su predložili da se naša centralna muzejska institucija predstavi u Hementemuseuma u Hagu jednim reprezentativnim izborom iz zbirki naconalne umetnosti, koji bi se sagledao u odnosu prema delima evropske Moderne koja se takođe čuvaju u Narodnom muzeju u Beogradu. Upravo je dr Silevis predložio da se napravi paralela između Beograda i Pariza, pri čemu se Pariz smatra središtem modernističkih tokova koji su odredili umetnost kasnog devetnaestog i prve polovine dvadesetog veka. Ovakav pogled znatno se razlikuje u odnosu na stanovišta koja su pratila izložbu Jugoslovenske savremene umetnosti. Razlozi za ovako izmenjeni pristup se pronalaze u tumačenjima koja su se formirala u teoriji moderne umetnosti tokom dvadesetog veka, a koja se zasnivaju na mišljenju o suživotu ili uporednim tokovima različitih kulturnih sredina $\mathrm{u}$ istom istorijskom periodu. Ovakva koncepcija izložbe uključila je i holandsku umetnost, odnosno pojedina dela koja su bila poklonjena 1931. godine. ${ }^{11}$ Takođe, 2004. su prikazana dela nekih umetnika koji su učestvovali na izložbi u Amsterdamu i Briselu 1932. godine. Oni su sada predstavljeni kao srpski umetnici, sa radovima nastalim u rasponu od 1900-1940. godine. Indikativno je upravo to što je 1932. u pitanju bila izložba jugoslovenskih umetnika koji su dolazili sa područja Kraljevine Jugoslavije u vremenima u kojima je još uvek bila očuvana predstava i slava hrabrih pobednika u Prvom svetskom ratu. Šezdeset i dve godine kasnije, u Hagu su isti ti umetnici dolazili iz zemlje koja je u evropskoj javnosti postala sinonim za ratne krivice i zločine. Ova izložba je nastala u atmosferi diplomatskog debakla Srbije i Crne Gore, u senci Haškog suda za ratne zločine, i to se osećalo prilikom rada na njoj. Da li je namera dr Silevisa, g-dina Van Krimpena i profesora Van Osa bila da poremete postojeću negativnu sliku o Srbiji, unoseći u nju sasvim drugačiji, čak i neočekivani sadržaj? Dr Silevis je, prema našem mišljenu, bio ključna osoba ne samo time što je osmislio koncepciju izložbe. Naime, ovakvom koncepcijom on je zapravo pokazao „kako nas drugi vide“. Imajući takvu ideju, on se zapravo našao u ekskulzivnoj poziciji da, kao stranac, osmisli koncepciju izložbe i da kao vodeći kustos objedini rad kustosa iz beogradskog muzeja. ${ }^{12}$

11 Jan Torop, „More“, Vinsent van Gog, „Seljanka u sobi“, Pit Mondrijan, „Kompozicija II“, Sillevis 2004: kat. br. 55, 22, 30 .

12 Uz dr Silevisa, na izboru dela i katalogu su radile kustoskinje Tatjana Bošnjak, Ljubica Miljkovič, Gordana Stanišič, Vera Grujić i Dragana Kovačić koja je ujedno bila i koordinatorka ovog projekta. 
Prikazujući zajedno dela naše i svetske Moderne, dr Silevis nije postavljao pitanje „uticaja“ kojim su se bavili u prošlom veku, već je upravo u tim uporednim tokovima otkrivao originalnost i svojstvenost srpske i jugoslovenske umetnosti. Sva ova dela su stajala i stoje u Narodnom muzeju, koji je kao i svaka muzejska institucija, vremenom, dao produženo ili čak redefinisao značenje pojedinačnih dela ili grupe dela. To „[...] ujedno svedoči i o ulozi i značaju institucije muzeja u formulisanju i kanonizaciji [...] pojedinačnih priča, podstičući pri tom i na preispitivanje potencijala i značenja upotrebe prošlosti, pitanja odnosa centra i periferije, problema internacionalne, ili čak nadnacionalne prirode jezika moderne umetnosti, kao i mogućih relacija između žive kulture i nasleđa koje muzej baštini [...]“ (Огњановић 2014: 47)

U salama Hementemuseuma su uporedo sa delima Nadežde Petrović, Leona Koena, Koste Miličevića, Save Šumanovića, stajala platna Vlamenka (Vlaminck), Pikasa (Picasso), Bonara (Bonnard), Monea (Monet). Pored radova konvencionalnog slikarskog postupka, koncepcijom izložbe bila su obuhvaćena i avangardna dela koja potiču iz zbirke Ljubomira Micića. Upravo je Zenit, internacionalna revija za umetnost $i$ kulturu, čiji je pokrtač i urednik bio Micić, tokom treće decenije dvadesetog veka, uspostavljala saradnju na međunarodnoj umetničkoj sceni, te tako i sa holandskim umetnicima K. A. Vilinkom (K. A. Willnik) i Jozefom Petersom (Jozef Peeters). Gradeći nezavisno svoju internacionalnu mrežu saradnika, Micić je avangardnim aktivizmom na jugoslovenskoj sceni stvarao uporedni tok $\mathrm{u}$ odnosu na zvanično priznatu umetnost. Milan Kašanin i kulturni poslenici Kraljevine Jugoslavije nisu bili naklonjeni radikalnim novinama i zbog toga se ova nova umetnost nije mogla naći u Stedelejku 1932. godine.

[Slika 3: Hementemuseum, maj 2004.]

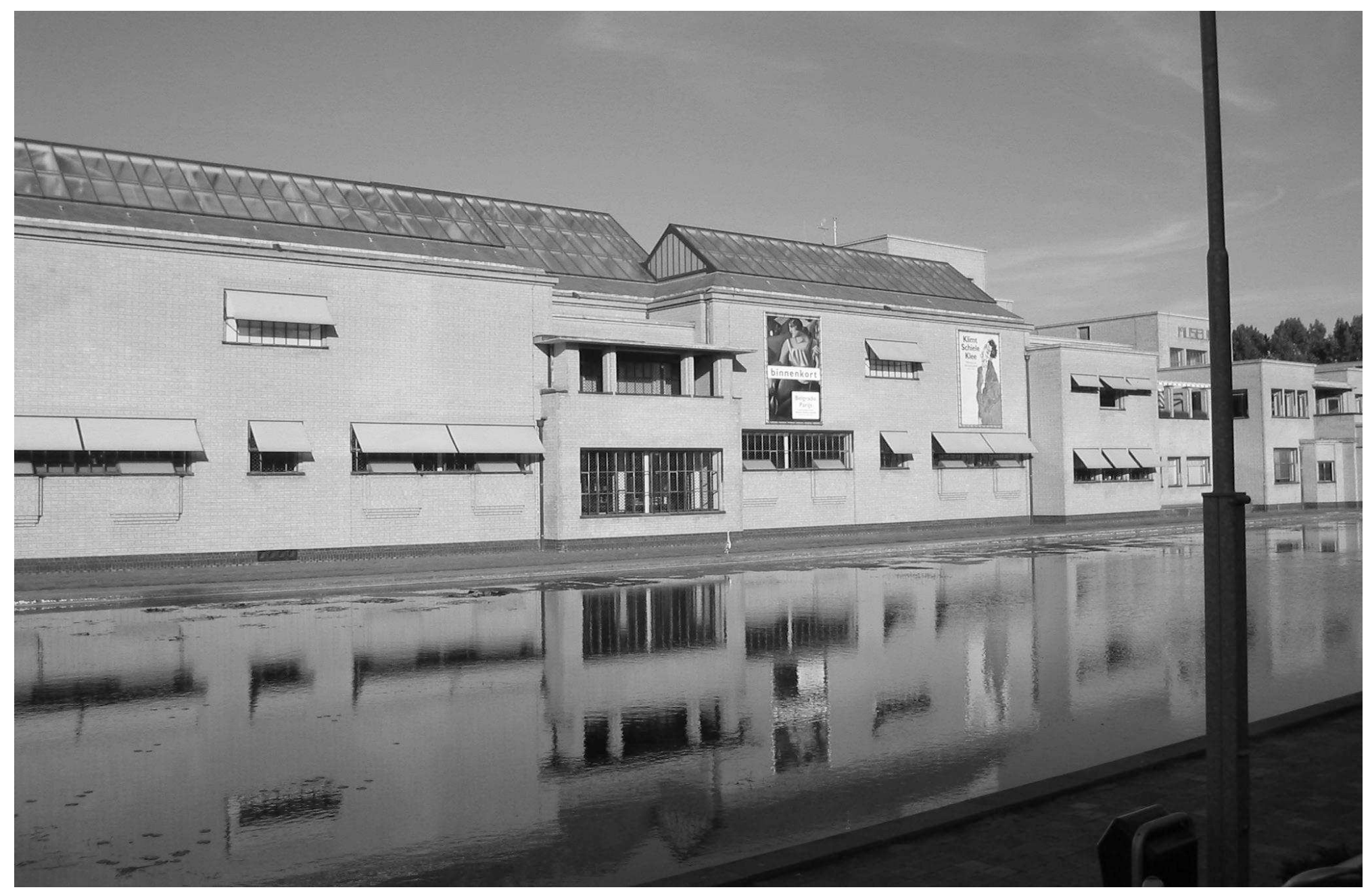




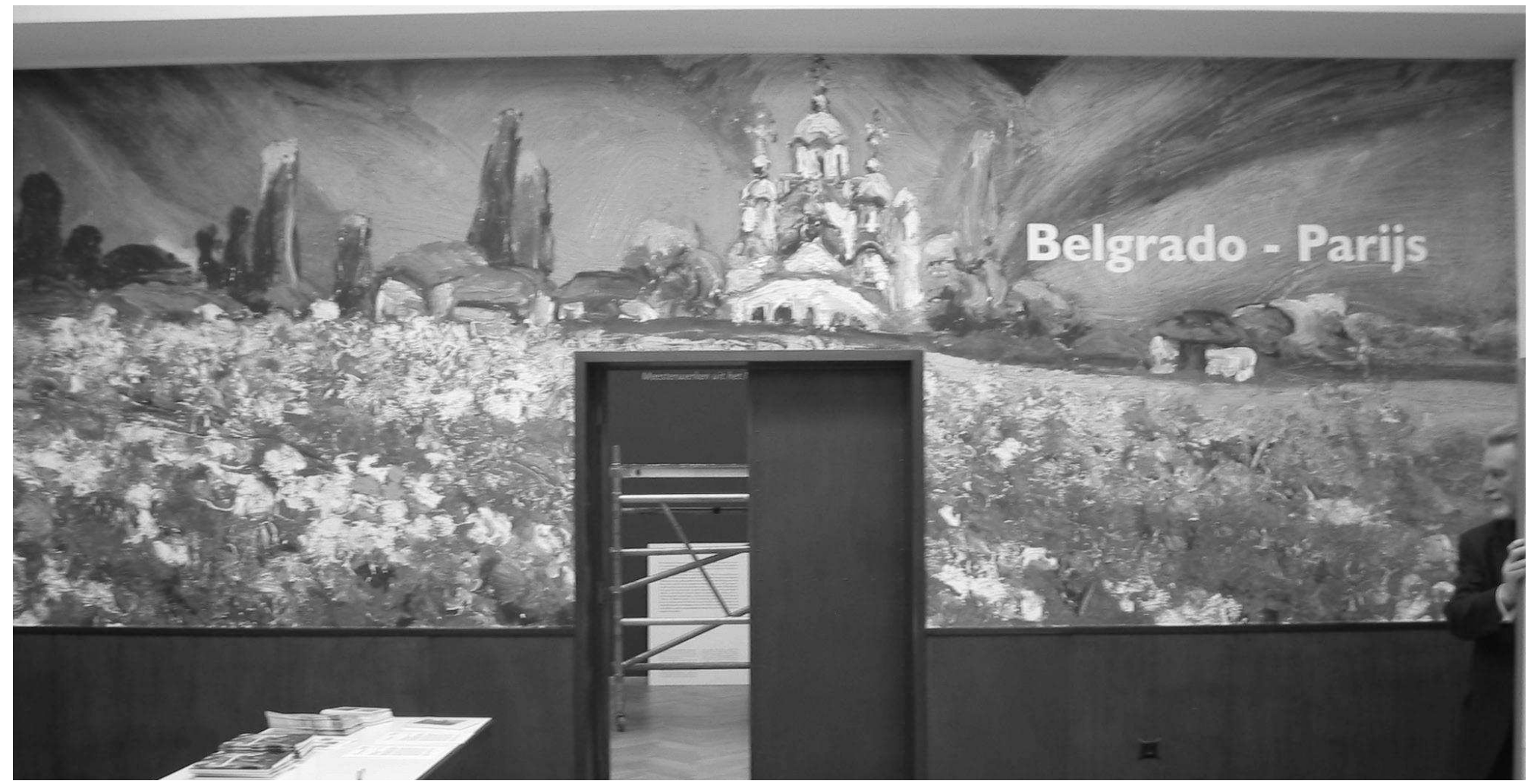

[Slika 4: Hementemuseum, Sa postavke izložbe „Beograd-Pariz. Remek-dela Narodnog muzeja u Beogradu, maj 2004.]

Na izložbi „Beograd-Pariz. Remek-dela Narodnog muzeja u Beogradu“ prikazano je ukupno sto osamdeset i osam dela iz pet zbirki Narodnog muzeja. Izložba je održana od 19. maja do 22. avgusta 2004. To je do današnjeg dana ostala najveća prezentacija Narodnog muzeja u inostranstvu, dok je u muzeološkom smislu reč o jednom veoma zahtevnom poduhvatu. ${ }^{13}$ Prema rečima kustosa iz Hementemuseuma, izložbu je videlo oko 35000 posetilaca, među kojima je bila i holandska kraljica Beatriks.

U medijskim izveštajima o ovom događaju dominiraju najave i osnovne infromacije. ${ }^{14}$ Tako BLUESTONES. WEB-LOG.NL na dan 20. maja 2004. objavljuje da je otvaranje „bilo veselo i zarazno“, te da su na otvaranju svirali mladi muzičari koji su došli iz Jugoslavije. [sic] Interesantno je da su zbirke Narodnog muzeja označene kao „do sada nepoznate“, pa je iznenađenje reportera bilo veliko kada je „otkrio“ našu avangardu, grupu Zenit i njen značaj za evropsku avangardnu scenu treće decenije dvadesetog veka.

521 Uitgevers polazi od Pariza kao centralnog mesta stvaranja moderne umetnosti, sa glavnim toponimima, Monmartrom i Manparnasom, kao obeležjima dve generacije umetnika iz druge polovine devetnaestog i prvih decenija dvadesetog veka, kada dolazi do naglašene internacionalizacije umetničkog miljea Pariza. Tu su, pored Modiljanija (Modigliani) i Van Dongena (Van Dongen), pomenuti naši umetnici, Nadežda Petrović, Šumanović, Konjović, i dr. koji su se, pored savremenika, susretali sa nasleđem kasnog devetnaestog veka. Posebno je, u ovom tekstu, istaknut značaj delovanja Zenit-a, koji je imao svoje predstavništvo u Parizu.

13 Ceremoniji otvaranja izložbe dat je značajan diplomatski nivo. Otvorile su je g-đa Maja Mitrović, ambasadorka Srbije i Crne Gore i g-đa Lujze Engering (Louise Engering), gradonačelnica Haga, koja je ujedno bila nadležna za kulturu u Skupštini grada Haga.

14 Tekstovi iz izvora: BLUESTONES.WEB-LOG.NL-a, https://www.uitgeverij521.nl/, i iz dnevnog tabloida SPITS preuzeti su iz presklipinga Izložbe - digitalna dokumentacija Narodnog muzeja u Beogradu. 
Novinar lista SPITS, Verschenen in SP!TS, Koromandel Brombaher (Coromandel Brombacher) daje, po našem sudu, najsadržajniji prikaz pod nazivom „Beograd se susreće sa Francuskom u Hagu“. Ovaj autor skreće pažnju na veliko bogatstvo moderne evropske umetnosti beogradske kolekcije, koju Beograd koristi kao brend u kome se nalazi imoguća korist, ne samo u preoblikovanju predstave o našoj sredini, privlačenju pažnje svetske javnosti, nego i materijalnom smislu. Brombaher je, očito, veoma dobro obavešten. On govori o predstojećoj rekonstrukciji zgrade Narodnog muzeja i potencijalnoj koristi koju izložba može da ima za beogradski turizam, jer „turisti tragaju za kulturnim blagom“. U izjavi za ovaj medij, dr Silevis je naglasio da je ova izložba posebno značajna jer pruža nove mogućnosti zemlji koja je zbog dugotrajnog rata ostala izvan umetničkih i kulturnih krugova Evrope. Svestan loših diplomatskih odnosa koji su posledica građanskog rata devedesetih, on je naglasio da umetnost uspeva u miru: „Umetnost nakon rata može biti sredstvo približavanja gradova i institucija." Takođe, on je podsetio da su odnosi između dve zemlje nekada bili dobri, o čemu svedoči donacija iz 1931. Mondrijanovu sliku „Kompozicija II“, koja bila prvo delo ovoga umetnika koje ušlo u jednu muzejsku zbirku, ocenio je kao „spektakularan komad iz dvadesetih godina, iznenađujuće dobro očuvan, što nije slučaj sa drugim njegovim delima." Silevis takođe izdvaja i saradnju Zenita sa grupom De Stejl (De Stijl), i skreće pažnju na poseban diskurs izložbe koji prati odnose Beograda i Pariza, što je na postavci i naglašeno, i što on smatra ,veoma uzbudljivim“. Na ovim premisama je u Hagu bila izvedena priča o jugoslovenskoj i srpskoj umetnosti, koja više nije bila posmatrana kao izdvojeni sadržaj koji treba „otkrivati“, nego kao autonomna umetnička sredina koja je nastala na autentičnomkulturnom nasleđu.

[Slika 5: Hementemuseum, dr Džon Silevis na konferenciji za novinare, maj 2004.]

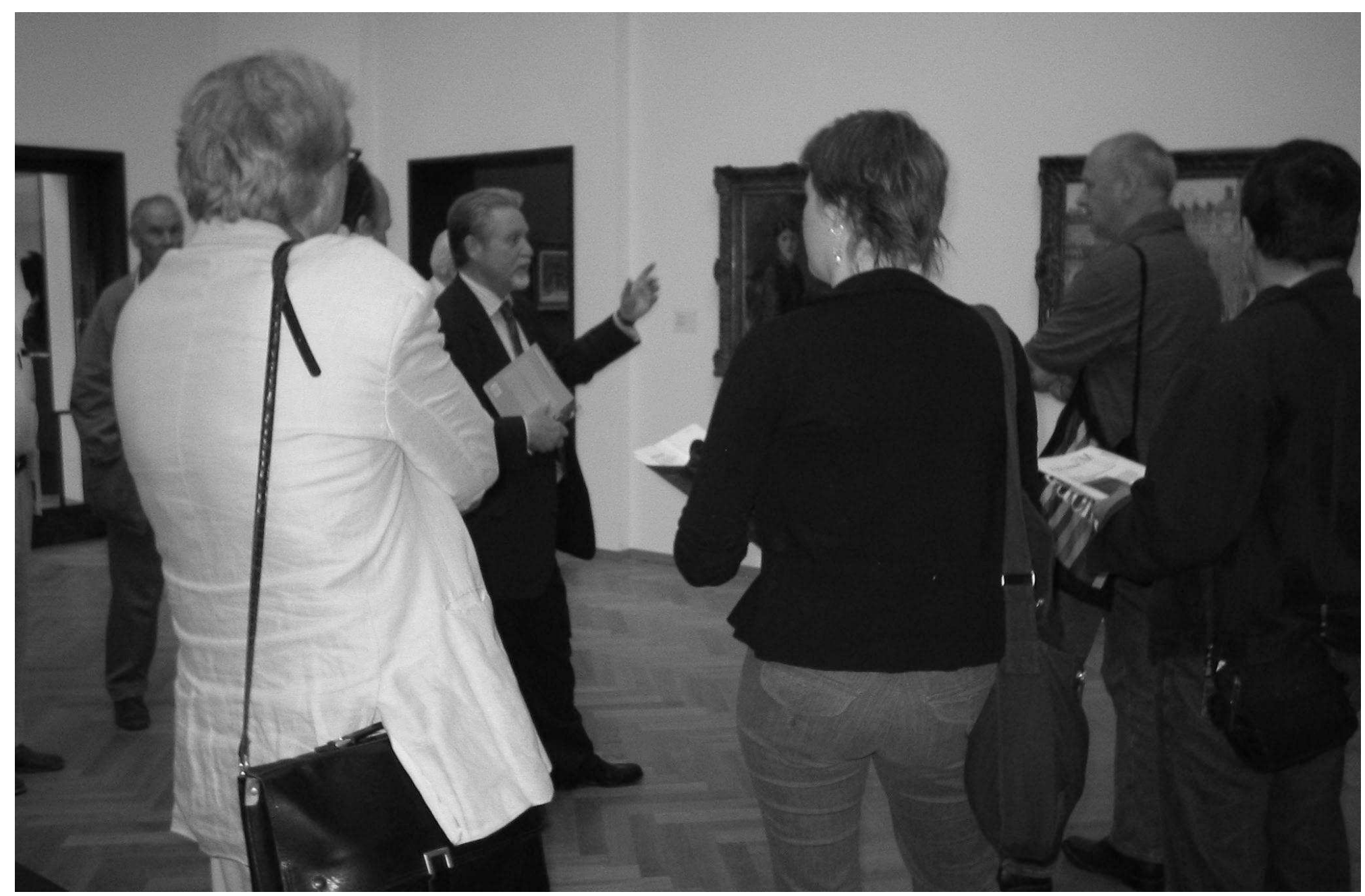




\section{Literatura}

Arhiv Jugoslavije Fond 66, fascikla 318-618.

Дергенц, Јелена. 2014. „Пит Мондријан и Композиција II.“ U: Дергенц J, Огњановић С, Пит Мондријан. Случај Композищије II, Београд: Народни музеј, 15-27.

Милошевић, Миладин. 2006. Дипломатски односи између Кратевине СХС и Краљевине Холандије 1918-1922, АJ 2006, 127-145 www.arhivyu.gov.rs/index.

Огњановић, Симона. 2014. „Модалитети рецепције и (ре)контекстуализације Композиције II.“ U: J. Дергенц, С. Огњановић, Случај Композиције II, Београд: Народни музеј, 35-99.

Кашанин, Милан. 1932. „Изложба у Амстердаму.“ Српски књижевни гласник 4, Београд, 311-312.

Kašanin, Milan. 1932a. Tenntoonstelling van Joegoslavische hedendaagsche beeldende kunst Catalogus : 24 september - 23 october 1932, Stedelijk museum, Amsterdam. Amsterdam: N.V. Van Munster's Drukkerijen.

Кашанин, Милан. 1933. Савремена наша уметност у светлости белгијске критике, Српски књижевни гласник 1, 63-66.

Said, Edvard. 2008. Orijentalizam, Beograd: XX vek.

Sillevis, John (ed). 2004. Belgrado - Parijs. Meesterwerken uit het Natonale Museum van Belgrado, Gemeentesmuseum Den Haag.

Cerović, Natalija. 2011. „Slike iz srca grada.“ Vreme 1076, 18. 08. 2011. http://www. vreme.com/cms/view.php?id=1006642 